\title{
Hypogenic origin of Provalata Cave, Republic of Macedonia: a distinct case of successive thermal carbonic and sulfuric acid speleogenesis
}

\author{
Marjan Temovski ${ }^{*}$, Philippe Audra ${ }^{2}$, Andrej Mihevc ${ }^{3}$, Jorge E. Spangenberg ${ }^{4}$, \\ Victor Polyak ${ }^{5}$, William McIntosh ${ }^{6}$, and Jean-Yves Bigot ${ }^{7}$ \\ Graduate School, University of Nova Gorica, Vipavska 13, 5000 Nova Gorica Slovenia \\ 2 Polytech Nice - Sophia, Engineering School of Nice - Sophia Antipolis University, 930 Route des Colles 06903 Sophia-Antipolis, IMREDD, France \\ ${ }^{3}$ Karst Research Institute ZRC SAZU, Titov trg 2, 6230 Postojna, Slovenia \\ ${ }^{4}$ Institute of Earth Sciences, University of Lausanne, Géopolis, 1015 Lausanne, Switzerland \\ ${ }^{5}$ Earth and Planetary Sciences, University of New Mexico, 200 Yale Blvd, Northrop Hall, Albuqueque, NM 87109 USA \\ ${ }^{6}$ New Mexico Bureau of Geology and Mineral Resources, New Mexico Tech, 801 Leroy Place, Socorro, NM 87801, USA \\ ${ }^{7}$ French Association of Karstology
}

\begin{abstract}
Provalata Cave (Republic of Macedonia) is a small but remarkable hypogenic cave, developed in Cambrian marbles by successive thermal carbonic and sulfuric acid speleogenesis. The cave has a thick partly corroded calcite crust, abundant gypsum deposits, with cupolas, ceiling and wall channels, feeders and replacement pockets as some of the most characteristic morphological features. Distribution of morphology and deposits suggest a hypogenic origin in two distinct speleogenetic phases: the first by thermal $\mathrm{CO}_{2}$ rich waters, the second by sulfuric acid dissolution, which were separated by complete infilling of cave passages with pyroclastic-derived clays. In the first phase of speleogenesis, cave passages were formed by dissolution along fractures due to cooling of rising carbonated thermal waters. These phreatic morphologies were later covered with a thick calcite crust deposited in a shallow phreatic environment. In Early Pleistocene the cave was completely filled with clays due to deposition of pyroclastic rocks in a lacustrine environment in the nearby Mariovo Basin. Mariovo Lake sediments were later incised by the Buturica River, which cut down into Cambrian marbles, creating its superimposed valley. Incision lowered the water table and allowed removal of the clay deposits in Provalata Cave. The second phase of speleogenesis started after introduction of $\mathrm{H}_{2} \mathrm{~S}$ associated with rising thermal waters. Oxidation produced sulfuric acid, which rapidly dissolved first calcite crust, then marble host rock. Condensation-corrosion by sulfuric vapors replaced carbonate rock with gypsum producing replacement pockets as well as second generation of pockets and cupolas. The contact of sulfuric acid with the clay deposits formed alunite, jarosite, and natroalunite. ${ }^{40} \mathrm{Ar} /{ }^{39} \mathrm{Ar}$ dating gave maximum ages of $1.6 \mathrm{Ma}$ (alunite) and $1.46 \mathrm{Ma}$ (jarosite) for this last stage of speleogenesis, thus making it the second ${ }^{40} \mathrm{Ar} /{ }^{39} \mathrm{Ar}$ dating of a sulfuric cave in Europe (after Kraushöhle in Austria), and the first dated cave in the Republic of Macedonia.
\end{abstract}

Keywords: $\quad$ sulfuric acid speleogenesis; thermal carbonic speleogenesis; hypogenic cave; Provalata Cave, Macedonia

Received 12 March 2013; Revised 17 July 2013; Accepted 21 August 2013

Citation: Temovski M., Audra P., Mihevc A., Spangenberg J., Polyak V., Mclntosh W. and Bigot J., 2013. Hypogenic origin of Provalata Cave, Republic of Macedonia: a distinct case of successive thermal carbonic and sulfuric acid speleogenesis. International Journal of Speleology, 42 (3), 235-246. Tampa, FL (USA) ISSN 0392-6672 http://dx.doi.org/10.5038/1827-806X.42.3.7

\section{INTRODUCTION}

Two major classes of hypogenic caves form due to dissolution of carbonate rocks: by $\mathrm{CO}_{2}$ and $\mathrm{H}_{2} \mathrm{~S}$ rich waters with frequent but not systematic thermal characteristics (Palmer, 1991; Dublyansky, 2000a).

Rising thermal carbonic waters cool down along their flow path, increasing their aggressiveness due to the inverse relationship between solubility and temperature, which leads to a progressive increase in $\mathrm{CaCO}_{3}$ solubility, and also a drastic drop of solubility near the water table due to the loss of $\mathrm{CO}_{2}$. As a result a geochemical zone of carbonate dissolution and zone of carbonate precipitation appear (Dublyansky, 2000a).

Where $\mathrm{H}_{2} \mathrm{~S}$ rich waters mix with shallower oxygen rich waters, sulfuric acid forms at or near water table, which rapidly dissolves the carbonate rocks (Egemeier, 1981). This process is known as sulfuric 
acid speleogenesis and has been recognized as a significant cave forming process in many caves around the world, such as Carlsbad and Lechuguilla caves in New Mexico (Hill, 2000), Frasassi Caves in Italy (Galdenzi \& Menichetti, 1995), Cueva de Villa Luz in Mexico (Hose \& Pisarowicz, 1999), Chat Cave in France (Audra, 2007), Cerna Valley caves in SW Romania (Onac et al., 2011), and Kraushöhle in Austria (Plan et al., 2012). Above the water table $\mathrm{H}_{2} \mathrm{~S}$ escapes in the cave air and redissolves in water condensation droplets on cave walls. There it oxidizes to sulfuric acid, which attacks the carbonate rock and converts it to gypsum by forming replacement gypsum crusts on cave walls and ceiling. Replacement gypsum crusts may detach and form mounds or blocks of massive gypsum on the floor (Egemeier, 1981; Galdenzi \& Maruoka 2003). Massive gypsum can also form below water table as a result of sulfate supersaturation of the groundwater, as documented in the caves of the Guadalupe Mountains in U.S.A where the rising water contained much sulfate that escaped reduction, which gave the water a head start in depositing subaqueous gypsum (Palmer \& Palmer, 2000); however such conditions for subaqueous gypsum remain seldom. In contact with alumino-silicates, sulfuric acid produces a characteristic suite of minerals such as alunite, jarosite, natroalunite, hydrated halloysite. The K-rich sulfate minerals formed during the speleogenesis, and Ar-Ar dating of these minerals have potential to yield the age of the cave forming process (Polyak and Provencio, 2001).

This paper presents results of a morphological study, combined with X-ray and stable isotope analyses of cave deposits, to determine the origin and evolution of Provalata Cave, a small cave in the southern part of the Republic of Macedonia (Fig. 1), formed on the edge of a Neogene coal bearing basin. The cave was first explored by caving clubs Peoni and Ursus Speleos from Skopje, and first published in the scientific literature (as Gulabinka Cave) by Kolčakovski et al.

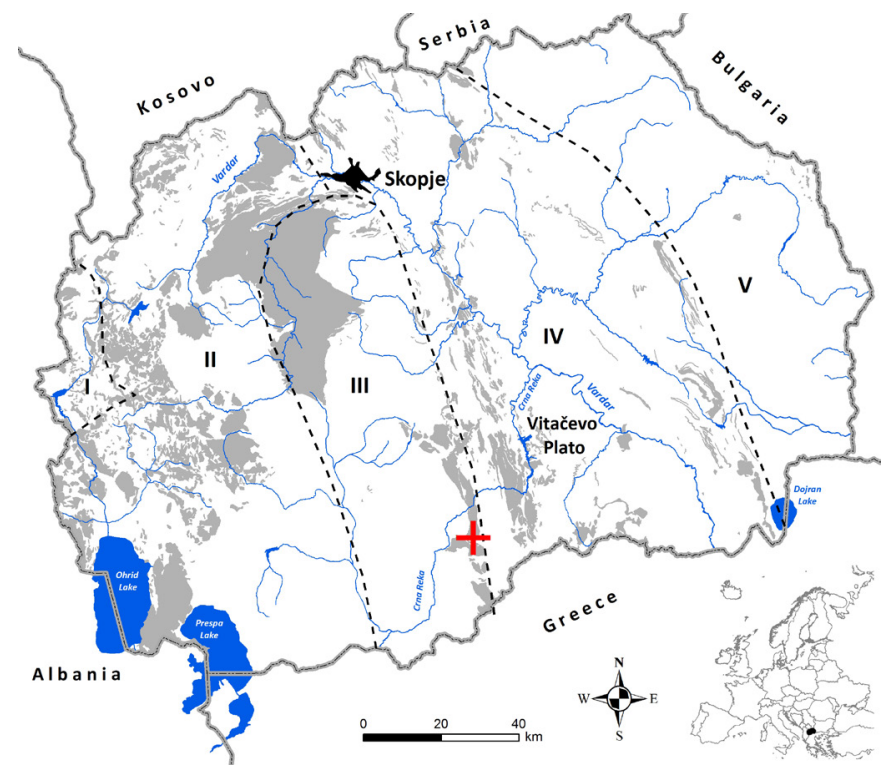

Fig. 1. Location of Provalata Cave (red cross) in the Republic of Macedonia. Karst rock outcrops are shown in grey shades. Major tectonic (pre-Cenozoic) units in Macedonia. I: Chukali-Krasta unit; II: Western Macedonian unit; III: Pelagonian Massif; IV: Vardar zone; and V: Serbo-Macedonian Massif.
(2004). They noted the presence of gypsum in the cave and suggested that the origin of the cave was connected with dissolution of marble by hydrothermal waters enriched with $\mathrm{H}_{2} \mathrm{~S}$, although concluded that the cave was a fossil ponor cave.

Our results suggest an origin in two recognizable speleogenetic phases, a first thermal carbonic phase responsible for the thick calcite crust and a second sulfuric acid phase creating abundant gypsum deposits.

\section{LOCATION AND GEOLOGICAL SETTING}

Provalata Cave is located near Melnica and Vitolište villages in Mariovo, in the southern part of Republic of Macedonia, on the eastern edge of a Neogene tectonic basin (Mariovo Basin), at the top of the southern slope of the superimposed valley of the Buturica River (Fig. 2). In a wider tectonic sense this area is part of the Pelagonian Massif, a pre-Cenozoic major tectonic unit, which consists of Precambrian gneiss and schist rocks, covered by a thick section of dolomitic and calcitic marble in the upper part, and with abundant granitic plutons (Dumurdžanov et al., 2005).

The cave is mostly formed in Cambrian marbles with some (mostly upper) parts formed in marble breccia, which together with the underlying Precambrian dolomitic marbles are part of the Veprčani Monocline that has a NNW-SSE direction and dips to the ENE by 25 to $50^{\circ}$. In the northern parts these Cambrian marbles have lenses of phyllito-micaschists, and to the south they lie directly over Cambrian phyllitomicaschists (Dumurdžanov et al., 1976). One such lense is located just west of the cave (the cave is formed near the contact of marbles and phyllito-micaschists).

To the south and east, these Pre-Cenozoic rocks are covered by Neogene and Quaternary lacustrine and pyroclastic sediments of the Mariovo Basin (Dumurdžanov et al., 2004) and are described as follows:

-Nerezi Formation (Upper Miocene) - gravel and sandstone; siltstone and silty claystone that grades upward into claystone and coal; and siltstone and sandstone followed by a hiatus.

-Solnje Formation (Pliocene) - poorly stratified gravel and sandstone, overlain by:

-Vitačevo Formation (Pliocene) - stratified tuff overlain by sandstone and gravel interbedded with beds of diatomite, tuff, and sandy claystone; travertine deposits, tuff-agglomerate and sandstone.

-Mariovo Formation (Pleistocene) - pyroclastic rocks with nine travertine layers and a 20-m-thick travertine deposit on top.

Dumurdžanov et al. $(2004,2005)$ interpret the evolution of the Neogene basins in Macedonia to consist of 5 cycles, with the Mariovo Basin forming in cycle II (late Miocene: late Sarmatian-Meotian), with a hiatus of deposition at the end of cycle III (Pontian). This hiatus may be a result of the Messinian Salinity Crisis, which influenced the Vardar zone at the end of the Nerezi Formation (Pliocene Gilbert-type delta was found in Dračevo, near Skopje; Clauzon et al., 2008). In 

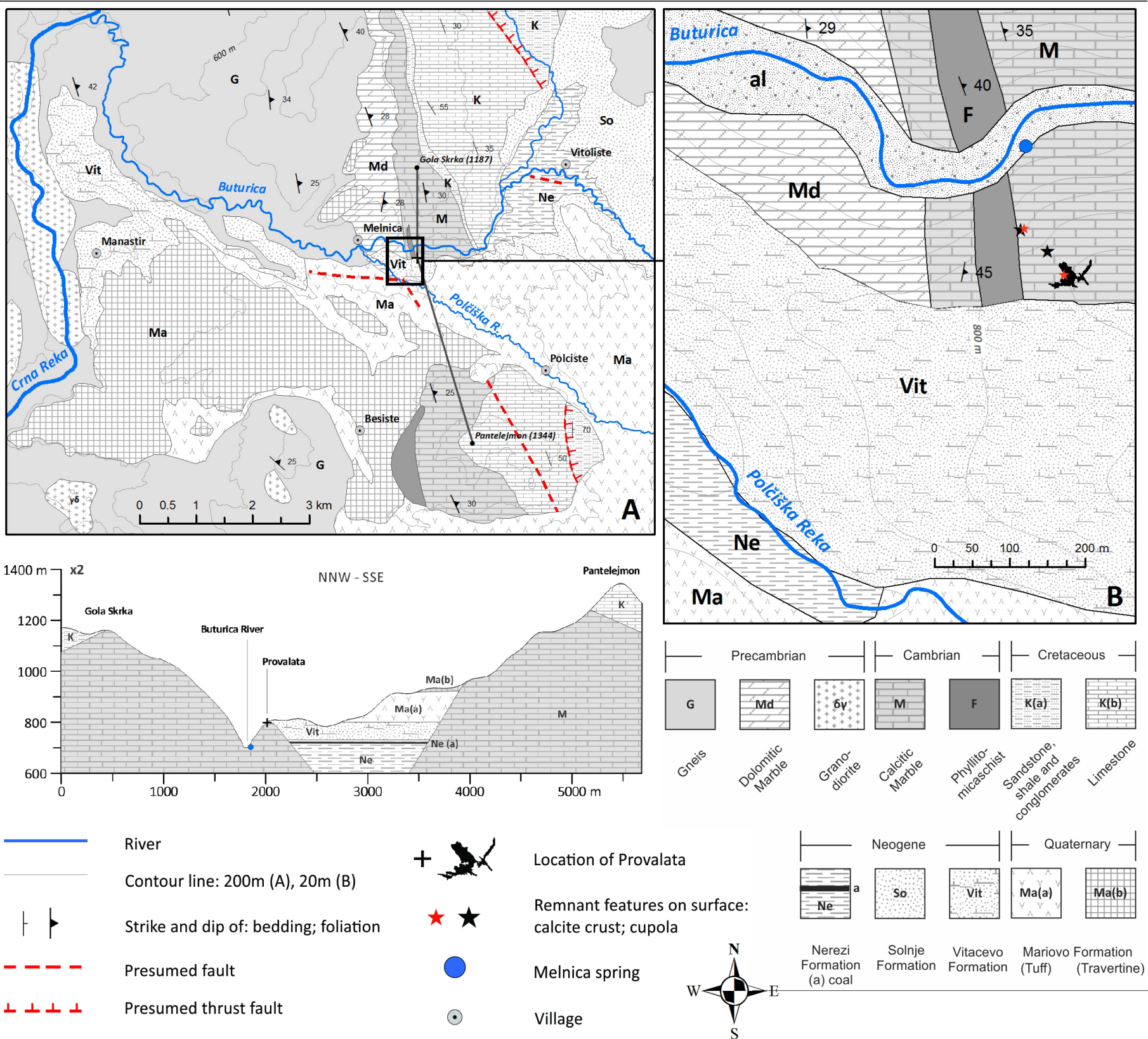

Location of Provalata

Remnant features on surface: calcite crust; cupola

Melnica spring

$\perp \Perp \perp \perp \quad$ Presumed thrust fault

$\odot \quad$ Village

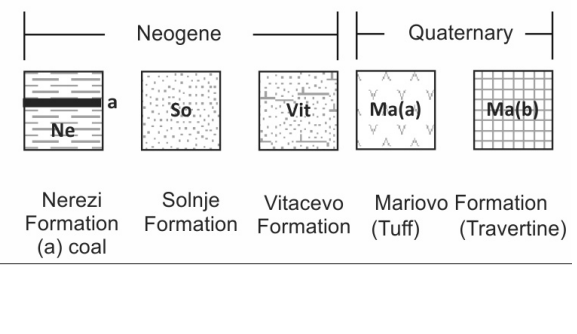

Fig. 2. Topographic and geological setting of Provalata Cave. Geological data after Dumurdžanov \& Hristov (1976).

Pliocene - cycle IV (Solnje Formation) a transgression occurred, accompanied by volcanic activity in Kožuf and Kozjak Mts. The Pliocene-Pleistocene Vitačevo and Mariovo Formations contain volcanic material and travertine. Draining of the lake systems in central Macedonia is a result of subsidence of the Aegean Sea (which started probably as late as Middle Pleistocene; Dumurdžanov et al., 2005). Mariovo Lake also drained, thus Crna Reka established its fluvial basin, including the superimposed valley of Buturica River in which Provalata Cave has formed.

\section{RESEARCH METHODS}

We made a detailed survey of the cave, combined with morphogenetic analyses in order to determine the presence of hypogenic morphologies.

Characteristic cave deposits were sampled for X-Ray analyses. This includes samples from gypsum, grey clay, yellow sand, pinkish clay, pale yellow sand and a dark crust under the gypsum crust. X-ray analyses were carried out at the CEREGE, France. X-ray powder diffraction (XRD) patterns were recorded on a Philips diffractometer using Cobalt radiation $(\lambda=1.79 \AA)$ with a secondary graphite monochromator. The diffractometer optic used to record all samples was a front fixed slit of $1^{\circ}$, a scattered radiation slit of $1^{\circ}$ after the sample, and a $0.2 \mathrm{~mm}$ detector slit. The $\mathrm{X}$-ray tube operating conditions were $40 \mathrm{kV}$ and $40 \mathrm{~mA}$ and the step-scan data were continuously collected over the range 3.5 to $78^{\circ} 2 \theta$ using a step interval of $0.05^{\circ} 2 \theta$ and a counting time of $2.5 \mathrm{~s} /$ interval.

Calcite crust, with a presumed thermal origin, was sampled for stable isotope analyses $\left(\delta^{13} \mathrm{C}, \delta^{18} \mathrm{O}\right)$. The sample was collected from the ceiling of a small channel emerging from the north part of the First Room. The $\delta^{13} \mathrm{C}$ and $\delta^{18} \mathrm{O}$ stable isotope ratios were measured at the Stable Isotope Laboratory at Saint Louis University (Department of Earth and Atmospheric Sciences), Missouri, USA. The isotopic ratio is given in per mil (\%o), according to VPDB international standard, with analytical error of $0.03 \%$ o and $0.06 \%$ or for $\delta^{13} \mathrm{C}$ and $\delta^{18} \mathrm{O}$, respectively. 
The sulfur isotope ratio of cave gypsum was analyzed at the Institute of Mineralogy and Geochemistry of the University of Lausanne using a Carlo Erba 1108 elemental analyzer (EA) connected to a Thermo Fisher (Bremen, Germany) Delta V isotope ratio mass spectrometer (IRMS) that was operated in the continuous helium flow mode via a Conflo III split interface (EA-IRMS). The stable isotope composition of sulfur is reported in the delta ( $\delta)$ notation as the per mil (\%o) deviation of the isotope ratio relative to known standards: $\delta=[($ Rsample - Rstandard $) /$ Rstandard $] \times 1000$, where $R$ is the ratio of the heavy to light isotopes $\left({ }^{34} \mathrm{~S} /{ }^{32} \mathrm{~S}\right)$. The sulfur standard is the Vienna Cañon Diablo Troilite (VCDT). The reference $\mathrm{SO}_{2}$ gas was calibrated against the IAEA-S-1 sulfur isotope reference standard $\left(\mathrm{Ag}_{2} \mathrm{~S}\right)$ with a $\delta^{34} \mathrm{~S}$ value of $-0.3 \%$. The overall analytical reproducibility of the EA-IRMS analyses, assessed by replicate analyses of three laboratory standards (barium sulfate, with a working $\delta^{34} \mathrm{~S}$ value of $+12.5 \%$; pyrite $\mathrm{Ch},+6.1 \%$; pyrite $\mathrm{E},-7.0 \%$ o) is better than $\pm 0.2 \%$ ( $1 \mathrm{SD}$ ). The accuracy of the $\delta^{34} \mathrm{~S}$ analyses was checked periodically by analyses of the international reference materials IAEA-S-1 and IAEA-S-2 silver sulfides $(0.3 \%$ ond $+22.7 \pm 0.2 \%$, respectively, values from IAEA-Catalogue and Documents) and NBS123 sphalerite $(+17.09 \pm 0.31 \%$, value from NISTCatalogue and Documents).

Samples of alunite and jarosite (pale yellow sand) were dated by the ${ }^{40} \mathrm{Ar} /{ }^{39} \mathrm{Ar}$ method at the New Mexico Geochronology Research Laboratory in Socorro, New Mexico, USA. Two aliquots of each sample were analyzed, one unwrapped and one wrapped in Ag with a platinum crimp. The second analysis was not a complete degassing. Results were similar for both the alunite and jarosite, but some higher step ages were apparent at the end of degassing, indicating minor to trace amounts of contamination from another older phase. Because of this, the results are considered maximum ages. Actual crystallization ages could be slightly younger.

Water from the small thermal spring below Provalata was sampled and analyzed for basic physical and chemical parameters, at the Center for Public Health in Prilep, Macedonia. Field measurements of pH, EC, and temperature were made with a HI 98129 (Hanna Instruments) multi-parameter tester.

\section{RESULTS}

\section{Cave morphology}

Provalata is a small cave with a total length of about $230 \mathrm{~m}$ and total depth of $24 \mathrm{~m}$. There are two major rooms (First and Second) with more or less vague (due to collapse) outlines, and two main passages (Lower and Upper) with more distinct (fracture guided) morphology (Fig. 3).

The most representative and common morphological features of the cave are cupolas and solution pockets (Fig. 4 A, D). Cupolas vary in form and size, often combining several cupolas overlain on another. They are most abundant in the Lower Passage as well as in the Upper Passage, but the highest ones (up to
$7 \mathrm{~m})$ are in the First Room, in marble breccia, as well as the entrance shaft which is a cupola formed in marble breccia opened to the surface by collapse. Two generations of cupolas and solution pockets can be clearly detected in the cave: one formed in marbles (or marble breccia) and covered with calcite crust, and the other formed in the calcite crust covering the first cupolas, or completely cutting through the calcite crust to the first generation cupola, and creating a secondary cupola or solution pocket.

Half tube wall channels are found in the Lower Passage, starting from feeders and leading to ceiling channels and cupolas (Fig. 4 C-F). They are 10-15 $\mathrm{cm}$ wide, mostly vertical and sometimes bifurcating. They rise from discrete small feeding channels along the floor sides, and lead to a central ceiling channel. The ceiling channel is curvilinear in plan view, 30$40 \mathrm{~cm}$ in diameter, and continues to SW to the neighbor passage rising in a big cupola. The small feeding channels have similar dimensions as the wall channels they lead to. The passage wall between rising wall channels is covered with white calcite popcorn speleothems. The popcorn distribution starts from the central ceiling passage downwards, with popcorn speleothems covering some of the half tube passages as well. Small gypsum crusts are also covering lower parts of passage walls with detached crust covering the floor near the walls. Along some prominent fractures the half tube wall channels lead to cupolas.

The genesis of this set of small feeding channels rising to half tube channels, which converge in a central ceiling channel is attributed to condensation corrosion, with the feeding channels representing vents supplying the rising moist air. Rising vapor from the vents cools and condenses at the contact with wall in upper parts producing film runoff due to accumulation of condensation. Cooler air that sinks warms up and produces evaporation. This leads to condensation-corrosion in the upper part, and evaporation-deposition in the lower part (Audra et al., 2007). The condensation-corrosion is largest at the ceiling producing the central ceiling channel, with popcorns and replacement gypsum deposited bellow the ceiling channel along the passage walls due to evaporation. The ceiling channel then continues to SW to the neighbor passage rising to a big cupola developed in calcite crust.

Gypsum replacement pockets (cf. Galdenzi and Marouka, 2003) can be found at several places with gypsum deposits already removed. In the Upper Passage they are developed in marble between two cupolas (Fig. 4 A, B), but replacement pockets formed in calcite crust can be also seen in the First Room. Their size ranges from few centimeters up to few decimeters in diameter.

\section{Cave deposits}

A calcite crust, black to transparent, up to $0.5 \mathrm{~m}$ thick and highly corroded (Fig. 5 E), is covering the walls and ceiling throughout the cave. In places it is completely corroded.

It covers various channel features with phreatic morphologies, such as cupolas, and solution pockets. 


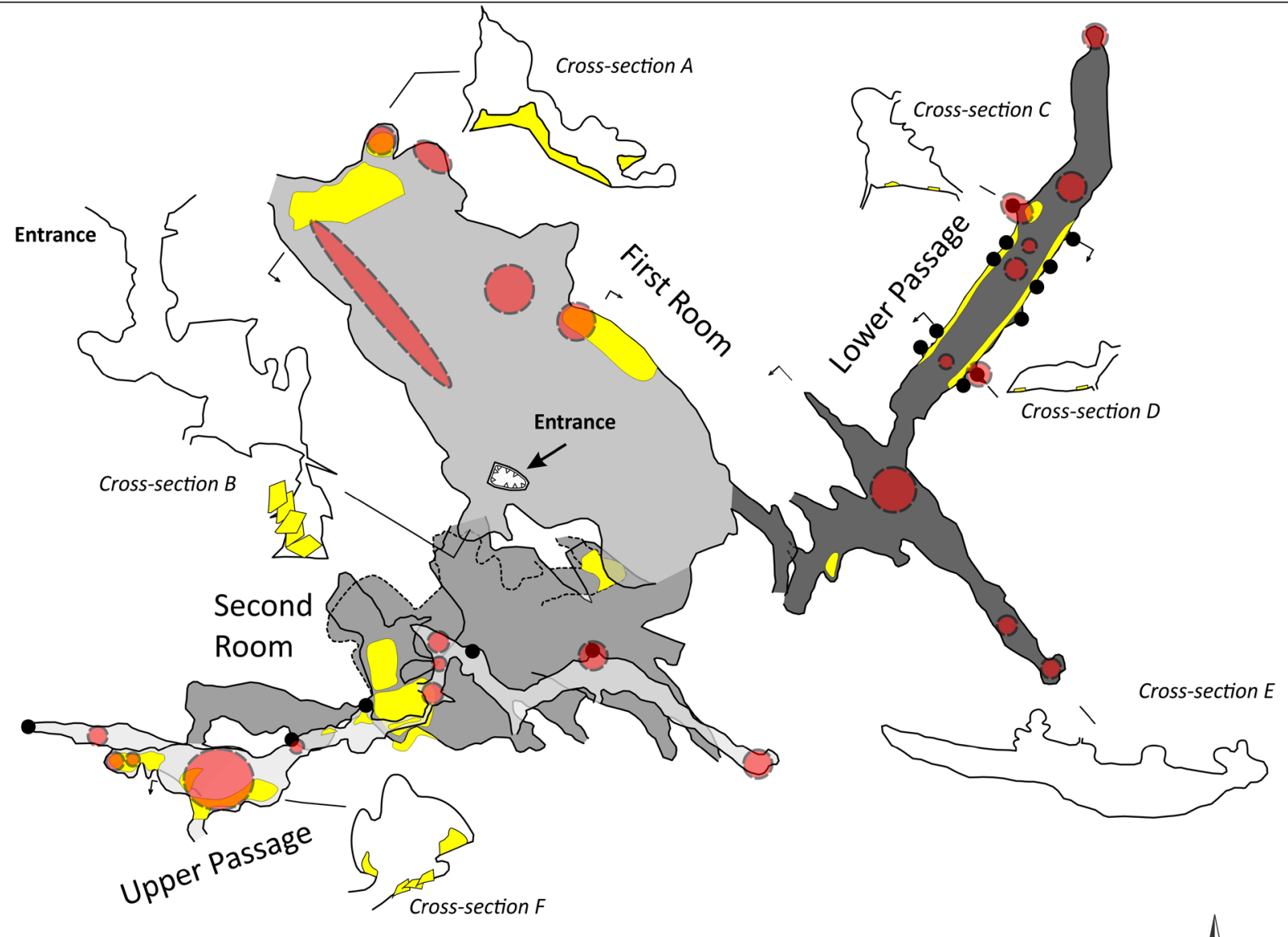

\section{CAVE PROVALATA}

Surveyed by:

Marjan Temovski, Zlatko Angeleski,

Mario Andonoski, Darko Jovanoski, 2010-2012

\section{Drawn by:}

Marjan Temovski, 2012

prominent cupolas

- feeding channels

larger gypsum deposits
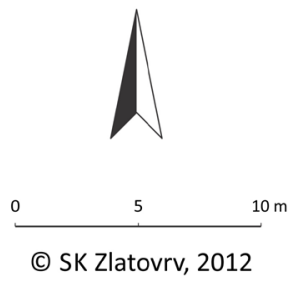

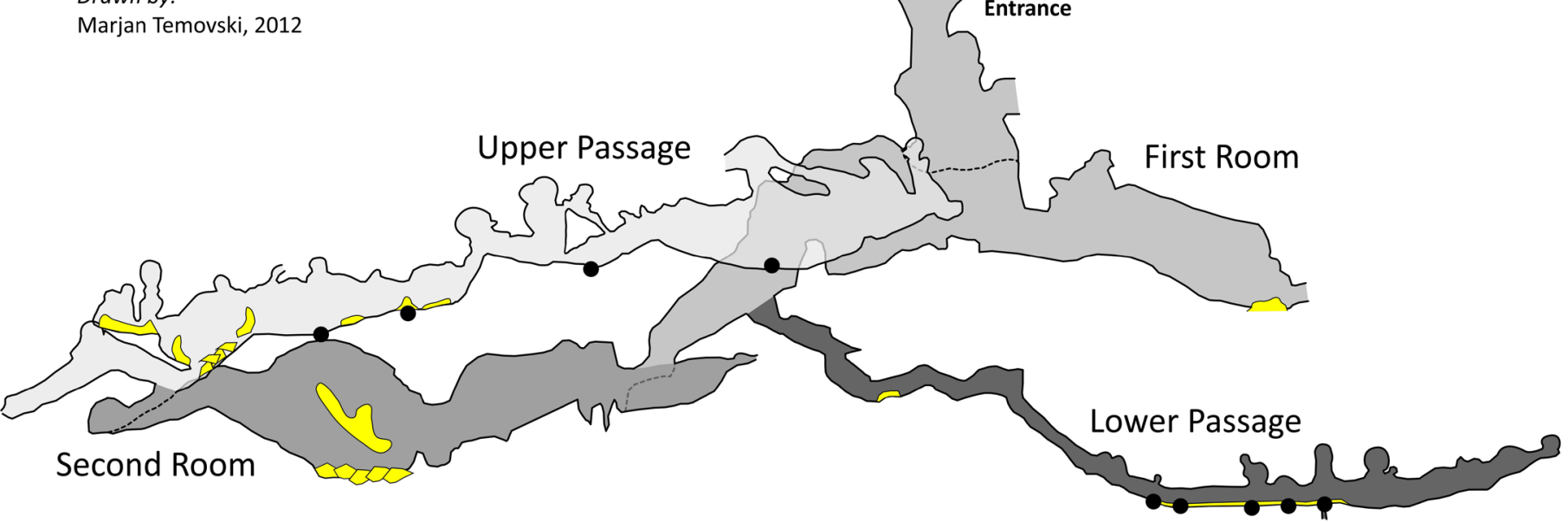

Fig. 3. Map of Provalata Cave.

The crust has mammillary morphology with mostly acicular calcite crystals. The morphology and thickness suggest formation by carbonic degassing in shallow thermal waters (Palmer, 1991; Dublyansky, 2000b; Audra, 2009a) preceding the clay infilling and sulfuric acid phase.

Five samples from a $\sim 20 \mathrm{~cm}$ cut through the calcite crust and marble host rock (Fig. 6) were collected for $\delta^{13} \mathrm{C}$ and $\delta^{18} \mathrm{O}$ analyses, two of which were from the weathered marble host rock $(\mathrm{C} 1, \mathrm{C} 2)$ and three from the calcite crust (C3, C4, C5). All of the five samples have light $\delta^{18} \mathrm{O}$ ratios $(-12.7$ to $-10.4 \%$ ), but quite heavy $\delta^{13} \mathrm{C}$ ratio (2.8 to $7.2 \%$ ). The values of $\delta^{18} \mathrm{O}$ are within the typical range for thermal calcite (Dublyansky, 2000b), but the values for $\delta^{13} \mathrm{C}$ are quite high for the calcite.

Grey clays (Fig. 5 B) cover the lower parts of cave passages, but small patches of grey clay can be found 

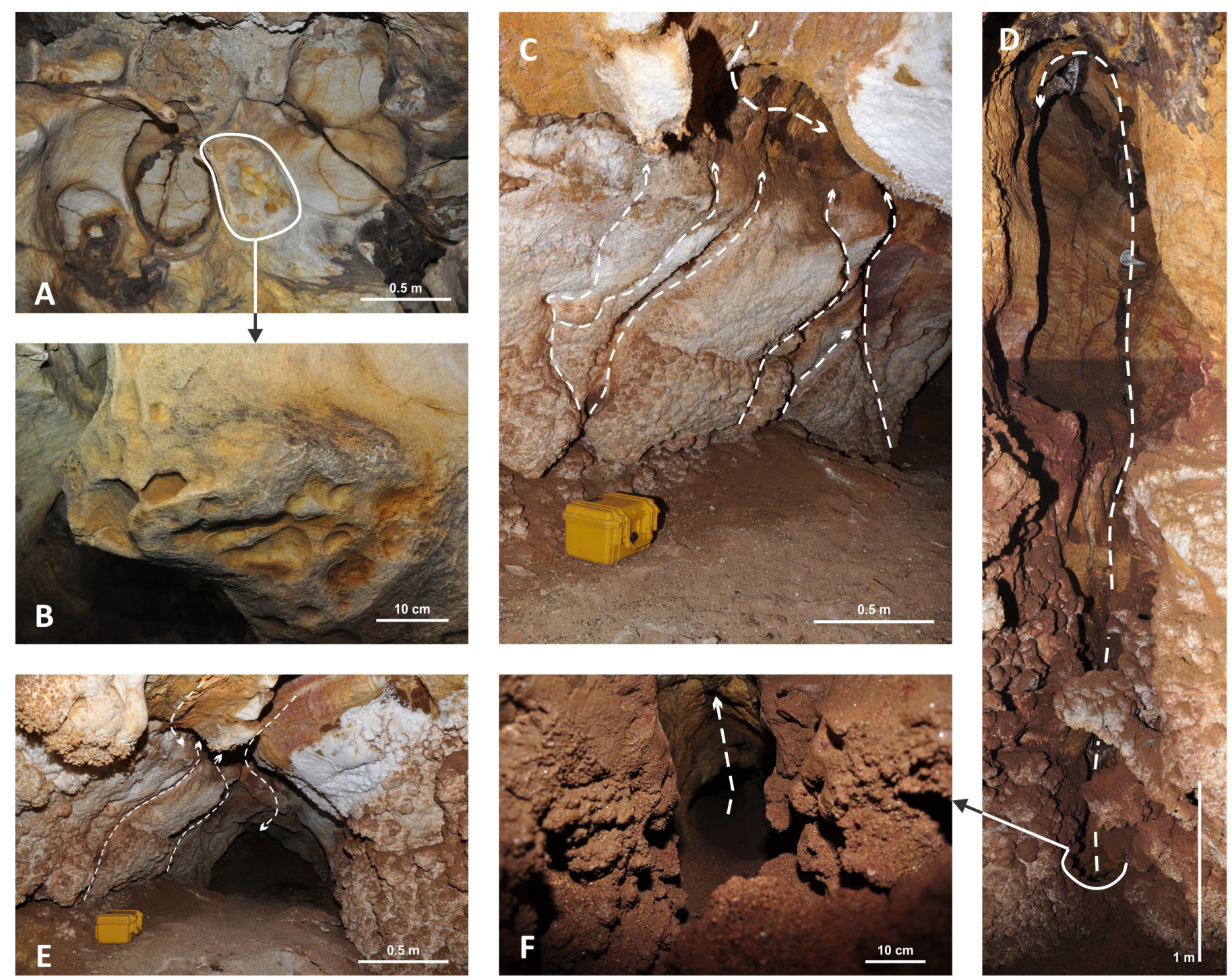

Fig. 4. Morphological features of Provalata Cave. A: Cupolas, with some replacement pockets in between; B: Replacement pockets on a pendant between cupolas; C: Small half tube wall channels rising from feeders to a ceiling channel; D: A suite of feeder leading to wall channel, rising to cupola at the top. Lower parts are covered with calcite popcorns (the horizontal line is due to photo merging); E: Continuation of the ceiling channel shown in $\mathrm{C}$, with some wall channels joining it; $\mathrm{F}$ : The feeder at the bottom of the rising suite at $\mathrm{D}$.

filling parts of cupolas in the Upper Passage, suggesting a complete infilling of the cave at some time, and later removal. X-ray analyses confirmed composition of sanidine, kaolinite, montmorillonite, albite, muscovite and quartz. Considering the composition, its origin is likely related to the overlaying pyroclastic sediments (tuff) of the Mariovo Formation. This is also suggested by results of X-Ray analyses of clays from caves (Aramiska Peštera, Dragoželska Propast, Čulejca) of the nearby Vitačevo Plato (Fig. 1), formed in limestones covered by similar pyroclastic sediments (Table 1).

Fine-grained pale yellow sands can be found in the First Room, covering the walls and ceiling, and filling fractures (Fig. 5 C). X-ray analyses of sample PR10 from the wall in the SE end of the First Room confirmed the presence of alunite, jarosite, quartz and muscovite (Fig. 7). ${ }^{40} \mathrm{Ar} /{ }^{39} \mathrm{Ar}$ dating of alunite and jarosite gave maximum ages of $1.6 \mathrm{Ma}$ and $1.46 \mathrm{Ma}$, respectively (Table 2).

Pink clay was found on the wall at the entrance part of the Lower Passage (Fig. 5 D). X-ray (sample PR08) confirmed a composition of halloysite, natroalunite, muscovite and quartz (Fig. 7). It has a white to pale pink color and it is dehydrated, with a waxy texture.
Gypsum deposits are the most characteristic cave deposits. They are found in every part of the cave, except some places, which have periodic vadose percolation, where gypsum most likely was dissolved.

Gypsum deposits are present as replacement crusts up to $40 \mathrm{~cm}$ thick (Fig. $5 \mathrm{~F}$ ), or detached replacement gypsum crusts (Fig. $5 \mathrm{G}$ ) that accumulated in gypsum blocks (Fig. $6 \mathrm{H}$ ). Preliminary stable isotopes analyses (Table 3 ) of sulfur from cave gypsum (2 samples) gave $\delta^{34} \mathrm{~S}$ values of -2.3 to $-1.9 \%$.

The origin of $\mathrm{H}_{2} \mathrm{~S}$ involved in the sulfuric acid speleogenesis of Provalata Cave might be attributed to the coal deposits, if we consider the proximity of the coal deposits in Mariovo Basin to Provalata Cave, and the fact that no sulfate rocks have been found in the stratigraphy in this part of Macedonia.

Sulfur in the coals from Mariovo Basin is found as organic sulfur, pyrite and gypsum (Lerouge et al., 2007). Gypsum in coals can be a weathering product of pyrite when occurring closely connected with pyrite, while gypsum in fine layers associated with calcite is considered to be formed by crystallization of calcium and sulfate ions dissolved in the pore water during the sedimentation (Lerouge et al., 2007). Total sulfur 

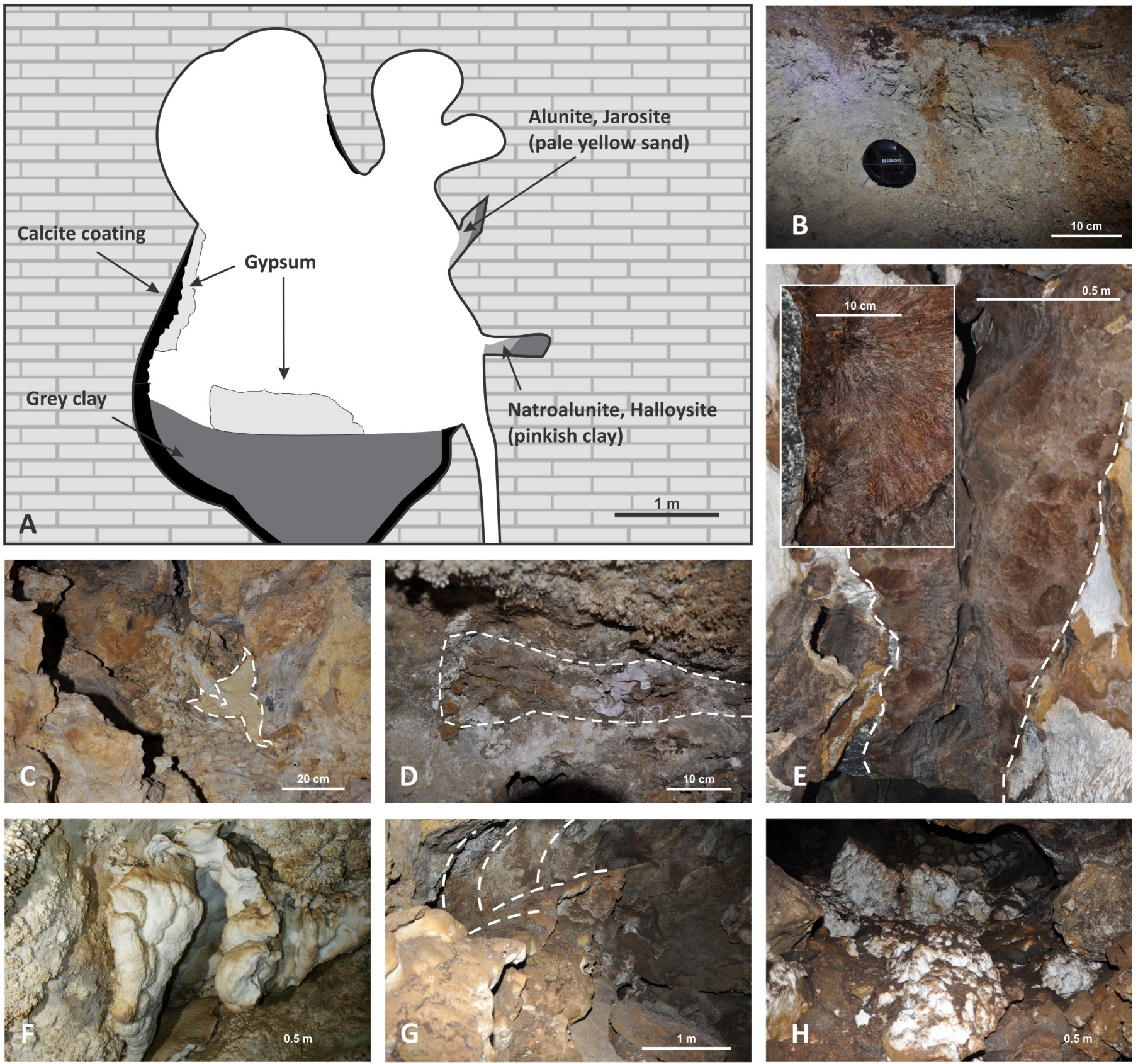

Fig. 5. Deposits in Provalata Cave. A: Schematic cross-section of sediments, showing stratigraphic relationships; B: Grey clay (montmorillonite, kaolinite, sanidine, albite, muscovite, quartz); C: Pale yellow sand (alunite, jarosite, muscovite, quartz); D: Pink clay (halloysite, natroalunite, muscovite, quartz); E: Corroded calcite crust; F: Replacement gypsum crust; G: Gypsum crust, detached from the wall; H: Detached gypsum crust piled as gypsum blocks.

Table 1. Mineralogical composition of clays from Provalata Cave and caves in the nearby Vitačevo Plateau.

\begin{tabular}{|c|l|l|}
\hline Cave & \multicolumn{1}{|c|}{ Sediment (sample) } & \multicolumn{1}{c|}{ Mineralogical composition } \\
\hline Provalata & Grey clay (PR04) & $\begin{array}{l}\text { montmorillonite, kaolinite, sanidine, } \\
\text { albite, muscovite, quartz }\end{array}$ \\
\hline Provalata & Pink clay (PR08) & $\begin{array}{l}\text { natroalunite, halloysite, muscovite, } \\
\text { quartz }\end{array}$ \\
\hline Provalata & Pale yellow sand (PR10) & alunite, jarosite, muscovite, quartz \\
\hline \multicolumn{2}{|c|}{ Caves in nearby Vitačevo Plateau } \\
\hline Dragoželska & Dark brown clay (DR01) & $\begin{array}{l}\text { montmorillonite, halloysite, illite, } \\
\text { quartz }\end{array}$ \\
\hline Aramiska Peštera & Pale brown clay (AR01) & $\begin{array}{l}\text { montmorillonite, kaolinite, sanidine, } \\
\text { fluorapatite, muscovite, quartz, }\end{array}$ \\
\hline Čulejca & Reddish-brown clay (CH) & $\begin{array}{l}\text { montmorillonite, halloysite, kaolinite, } \\
\text { calcite, muscovite, quartz }\end{array}$ \\
\hline
\end{tabular}

content in the coals is low, 1.18 to $1.3 \%$ (Raleva et al., 2012), with high sulfur content in macerals (1.2 to $2.3 \%$ ), showing that measured sulfur can be attributed to organic matter (Lerouge et al., 2007). $\delta^{34} \mathrm{~S}$ values are ranging from +8.5 to $+17.3 \%$ o for gypsum in coal seams and from +5.4 to $+13.2 \%$ for vitrinite.

Considering the complexity of sulfur isotopic evolution that can derive from generation of $\mathrm{H}_{2} \mathrm{~S}$ by bacterial sulfate reduction or thermochemical sulfate reduction, depending on paucity and/or supply of hydrocarbon electron donors and sulfate (Wynn et al., 2010), as well as modification due to contribution of secondary source of S (e.g., pyrite, Onac et al., 2011), further stable isotope analyses of cave gypsum, coal and sulfate of Melnica spring are necessary to determine the origin and evolution of sulfur participating in the sulfuric speleogenesis of Provalata Cave. 
Table 2. Summary of ${ }^{40} \mathrm{Ar} /{ }^{39} \mathrm{Ar}$ results.

\begin{tabular}{|c|c|c|c|c|c|c|c|c|c|}
\hline Sample & Lab \# & Irradiation & Mineral & Age analysis & Steps/analyses & Age (Ma) & $\pm 2 \sigma$ & MSWD & Comment \\
\hline Provalata-a & 60983 & 247 & alunite & laser step-heat & 3 & 1.60 & 0.05 & 1.03 & maximum age \\
\hline Provalata-j & 60984 & 247 & jarosite & laser step-heat & 3 & 1.46 & 0.03 & 1.19 & maximum age \\
\hline
\end{tabular}

Calcite popcorns are covering the corroded calcite crust at various places. Also small flowstone deposits are developing in a few places in the cave as a result of late vadose percolation.

\section{Remnant features on the surface}

Remnants of cupolas and solution pockets are also found on the surface, in the small gully in the gorge, which follows the contact of marbles and the phyllitomicaschist lens. Remnants of a similar calcite crust can be found on the surface, near the entrance of the cave (Fig. 2 B; Fig. 8).

\section{Melnica spring}

In 2010, a small spring in the riverbed of the Buturica River, just below Provalata Cave (Fig. 2 B), reemerged after (according to the local population) $\sim 40$ years of inactivity. The spring is discharging at several locations along the left bank of Buturica River, near the contact of Cambrian marbles with a lens of phyllito-micaschists. Considering that both Provalata Cave and the spring are located along the contact of marbles with phyllito-micaschist lens, and remnants of cupolas with calcite are found in between, along the same contact, the spring might be the present discharge point of the same system that formed Provalata Cave.

Preliminary analysis of some physical and chemical parameters show slightly thermal waters $\left(20-22^{\circ} \mathrm{C}\right)$, with a high amount of dissolved solids, EC values from 891-972 $\mu \mathrm{S} / \mathrm{cm}$, and slightly acidic $\mathrm{pH}$ ranging from 6.62-6.9 (Table 4).

If Melnica spring is considered as a late stage phase of Provalata Cave evolution due to incision of Buturica River, then the question of cease of sulfuric

Table 3. Stable isotope analyses results from marble, calcite crust $\left(\delta^{18} \mathrm{O}, \delta^{13} \mathrm{C}\right)$, gypsum and vitrinite $\left(\delta^{34} \mathrm{~S}\right)$ from Provalata Cave and nearby coals.

\begin{tabular}{|c|c|c|c|c|}
\hline Location & Sample & $\delta^{34} \mathrm{~S}(\% 0)$ & $\delta^{18} \mathrm{O}(\% 0)$ & $\delta^{13} \mathrm{C}(\%)$ \\
\hline \multirow{6}{*}{$\begin{array}{l}\text { Coal seams nearby } \\
\text { Vitoliste village } \\
\text { (Lerouge et al., 2007) }\end{array}$} & Gypsum (7K) & 17.2 & & \\
\hline & $\mathrm{MgSO}_{4}(7 \mathrm{~K})$ & 14.9 & & \\
\hline & Gypsum (8L) & 17.3 & & \\
\hline & Gypsum (8R) & 8.5 & & \\
\hline & Vitrinite $(8 R)$ & 13.2 & & \\
\hline & Vitrinite $(8 \mathrm{M})$ & 5.4 & & \\
\hline \multirow{7}{*}{ Provalata Cave } & Cave gypsum (P4) & -2.1 & & \\
\hline & Cave gypsum (P5) & -2.2 & & \\
\hline & Marble (C1) & & -10.6 & 4.9 \\
\hline & Marble (C2) & & -10.4 & 2.9 \\
\hline & Calcite crust (C3) & & -11.8 & 6.8 \\
\hline & Calcite crust (C4) & & -11.9 & 7.2 \\
\hline & Calcite crust (C5) & & -12.7 & 6.7 \\
\hline
\end{tabular}

acid dissolution remains. If origin of $\mathrm{H}_{2} \mathrm{~S}$ for Provalata Cave sulfuric acid speleogenesis is attributed to the nearby coal deposits, then the sulfuric phase can be a temporal manifestation, which ceased after lowering of water table below the elevation of the coal field. Further analysis of Melnica spring chemistry, cave gypsum and Mariovo coal deposits are needed for this hypothesis to be tested.

\section{DISCUSSION}

The thick mammillary calcite crust was deposited in shallow phreatic environment by thermal waters, filling previously formed passages and convectional features (cupolas, pockets) formed in a previous phase in deeper parts of the thermal system due to cooling effect of rising carbonated thermal waters.

The cave was later completely filled with clay deposits (Fig. 9), originating from weathering of pyroclastic sediments most likely from Mariovo Formation, which were deposited in a lacustrine environment in Early Pleistocene (Dumurdžanov et al., 2004).

Presence of alunite, jarosite, natroalunite in altered clay deposits, combined with large deposits of gypsum found as replacement crusts or gypsum blocks, and morphological features such as gypsum replacement pockets point towards dissolution by sulfuric acid.

Gypsum replacement crusts in sulfuric caves are considered to be of sub-aerial origin by condensation of $\mathrm{H}_{2} \mathrm{~S}$ rich vapors on carbonate rock (Galdenzi and Marouka, 2003; Palmer, 2007, 2013). In Provalata Cave they are found covering walls in several locations, with best examples found in the Second Room and Upper Passage, where detached crust are found piled below still standing wall crusts.

Morphological features such as pockets and cupolas developed in calcite crust, as well as trough the calcite crust in the marble host rock suggest second phase of dissolution after the deposition of the calcite crust. Based of their association with gypsum deposits (gypsum replacement crusts and replacement pockets found on calcite crust), their origin is attributed to dissolution by sulfuric acid. At places these second generation cupolas are also connected to feeders and wall and ceiling half tube channels. Such features are often indicative of convective cells in phreatic conditions (the "morphological suite of rising flow", Klimchouk, 2007), but can be also formed by condensation corrosion above the water table, by highly corrosive vapors (Audra, 2007; Audra et al., 2007, 2009b; Palmer, 2013). The rising suite in the Lower Passage was produced by condensation corrosion with the small feeding channels representing vents supplying rising moist air, with condensation-corrosion producing half tube wall and ceiling channels and popcorn speleothems and gypsum crust depositing in the lower parts due to evaporation. 


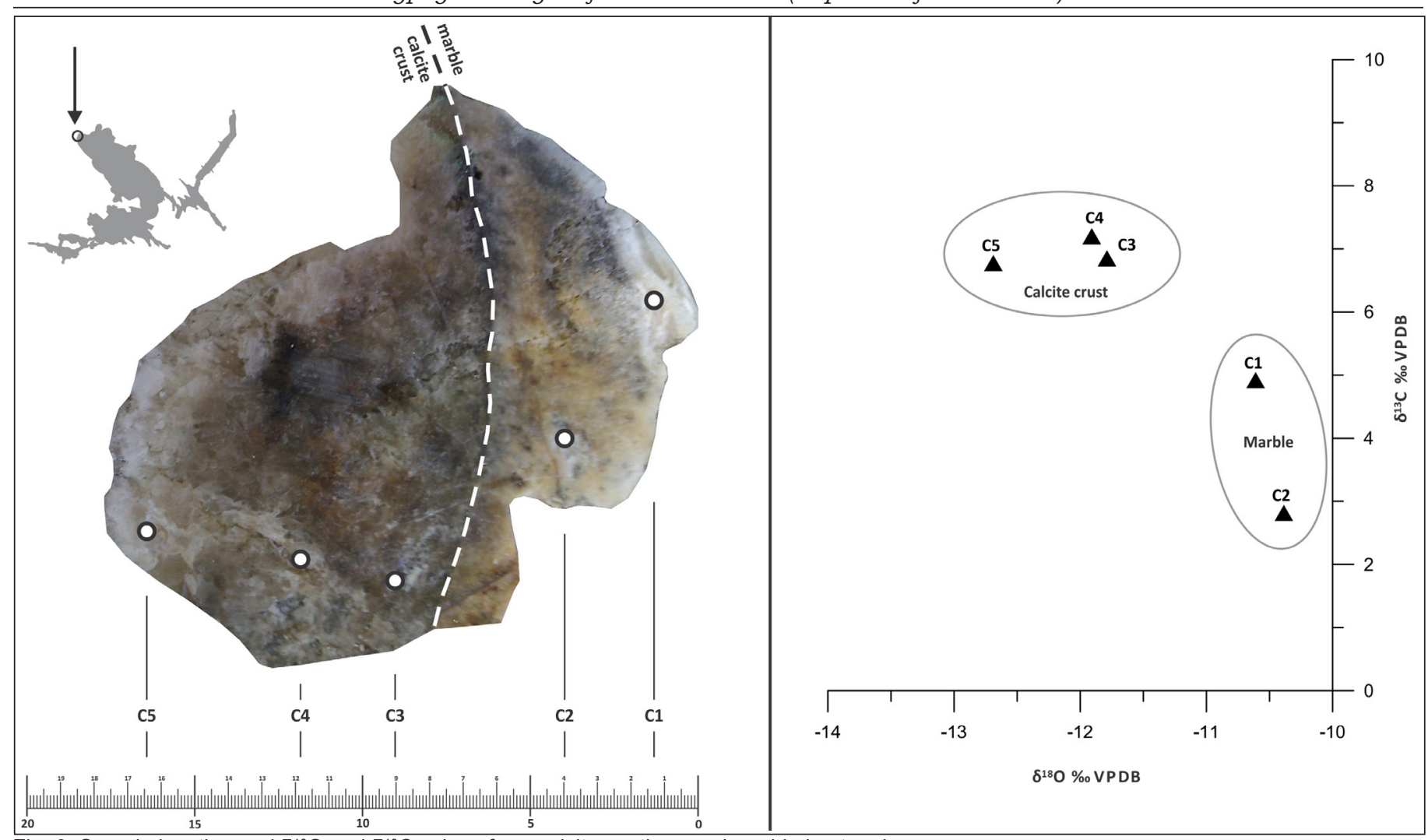

Fig. 6. Sample location and $\delta^{18} \mathrm{O}$ and $\delta^{13} \mathrm{C}$ values from calcite coatings and marble host rock.

The sulfate minerals (alunite, natroalunite, and jarosite) are clear evidence of alteration of clay by sulfuric acid (Polyak and Provencio, 2001). As pointed by Palmer $(2007,2013)$ alunite is formed by alteration of clay by low pH (less than 4) sulfuric acid. Sulfuric acid is most likely to reach such low $\mathrm{pH}$ needed to produce the alunite only in vadose moist droplets on clay (Palmer, 2007, 2013). The distribution of deposits and morphology connected with the sulfuric acid speleogenesis indicates that most of the dissolution in the sulfuric phase was above the water table by condensation-corrosion. Typical water table morphology such as corrosion tables, flat roof notches (Audra, 2007; Audra et al., 2009b) should be expected to develop in such environment. This was not evident in Provalata Cave and the absence of such morphology might be due to the presence of the formerly deposited grey clay. Covering the passage floors, the clay might have shielded the calcite crust or marble host rock from aggressive sulfuric waters or such morphology is located in a lower (presently not accessible) part of the cave.

${ }^{40} \mathrm{Ar} /{ }^{39} \mathrm{Ar}$ dating of alunite and jarosite from the First Room gave maximum age of 1.6 and $1.46 \mathrm{Ma}$. Considering their formation in a vadose environment, such condition could have been achieved only after the draining of Mariovo Lake and incision of the Buturica River Valley.

Since last layers of tephra can be found in the travertine layers deposited in lacustrine environment as end part of Mariovo formation, with volcanic activity in Kozjak (Kožuf) Mt. active from
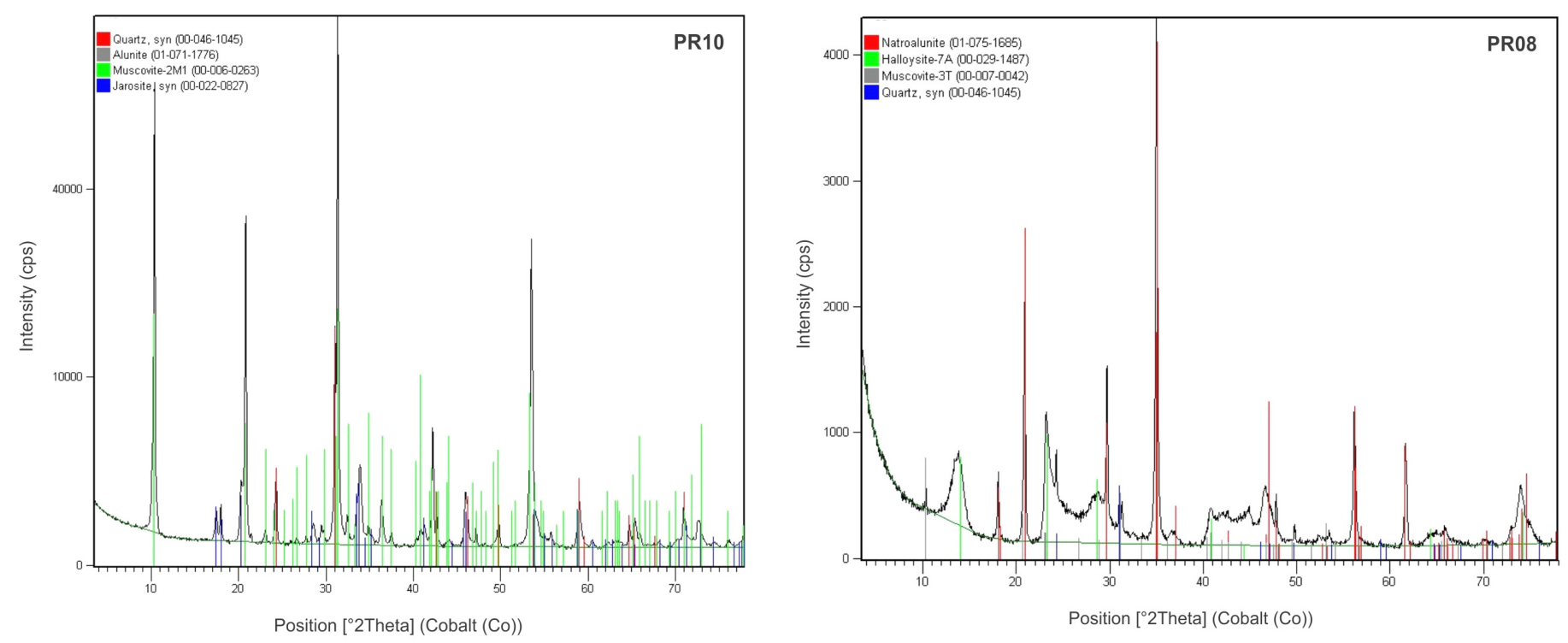

Fig. 7. XRD results for samples PR10 (jarosite, alunite), and PR08 (natroalunite). 

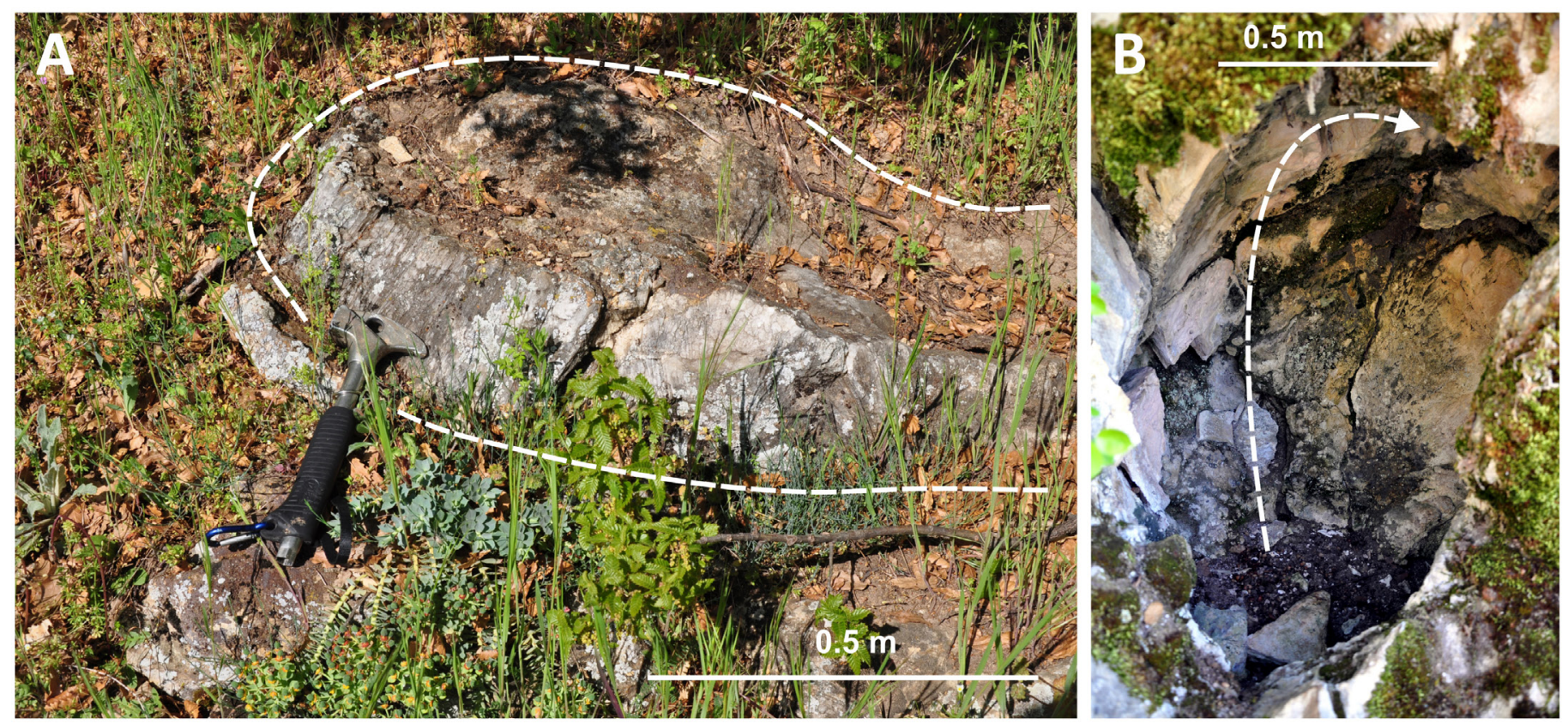

Fig. 8. Remnant cave features on surface near Provalata Cave. A: Calcite crust close to the entrance of Provalata Cave; B: Cupola exposed on Buturica Valley slope, close to the contact of marbles with phyllito-micaschist.

$4.0 \pm 0.2$ to $1.8 \pm 0.1 \mathrm{Ma}$ (Kolios et al., 1999), and with the oldest maximum age of cave alunite at 1.6 Ma we can place the draining of Mariovo Lake, and onset of fluvial drainage somewhere between 1.8 and $1.6 \mathrm{Ma}$.

With further incision of Buturica River, cave features (cupolas, pockets, calcite crust) were exposed on surface on the valley slope, due to slope retreat. The low thermal Melnica spring found below the cave in the river bed is likely the present discharge point of the system.

Considering this, the calcite crust and the cave features covered by it, which represent the first thermal carbonic phase, formed before deposition of Mariovo Formation and are probably from Late Pliocene-Early Pleistocene age.

\section{CONCLUSIONS}

Provalata Cave is a small but remarkable cave in the southern parts of Republic of Macedonia, with two successive phases of thermal carbonic, then sulfuric acid speleogenesis, separated by deposition of pyroclastic-derived clay deposits. It is also the

Table 4. Some basic physical and chemical parameters of the Melnica thermal spring

\begin{tabular}{|c|c|c|c|c|c|c|c|c|c|c|c|c|}
\hline$\frac{0}{\pi}$ & 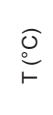 & I & 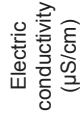 & 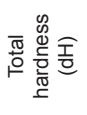 & 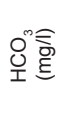 & ऽ̋ & 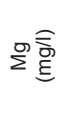 & ᄋำ & $\overline{0} \widehat{\bar{్}}$ & ષ્ઠ & ᄋ & 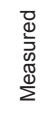 \\
\hline $\begin{array}{l}21 / 07 \\
2012\end{array}$ & 22 & 6.9 & 891 & 18.6 & 634.4 & 105.7 & 34.64 & 3.18 & 8 & 0 & 14.7 & lab \\
\hline $\begin{array}{l}24 / 11 \\
2012\end{array}$ & 21.5 & 6.64 & 945 & I & 1 & 1 & 1 & 1 & 1 & 1 & I & field \\
\hline $\begin{array}{l}27 / 01 \\
2013\end{array}$ & 21 & 6.74 & 892 & I & 1 & I & 1 & I & 1 & I & I & field \\
\hline $\begin{array}{l}09 / 02 \\
2013\end{array}$ & 20.6 & 6.62 & 914 & 1 & 1 & 1 & 1 & 1 & 1 & I & I & field \\
\hline $\begin{array}{l}24 / 02 \\
2013\end{array}$ & 21.1 & 6.7 & 972 & 1 & 1 & 1 & 1 & 1 & 1 & 1 & 1 & field \\
\hline
\end{tabular}

second ${ }^{40} \mathrm{Ar} /{ }^{39} \mathrm{Ar}$ dated sulfuric acid cave in Europe, after Kraushöhle in Austria, and the first dated cave in Republic of Macedonia.

Two sets of morphologies associated with different sets of deposits were identified and attributed to two separate speleogenetic phases: phreatic morphologies (cupolas) formed by cooling of rising carbonated thermal waters, covered with mammillary calcite crust (first phase); vadose morphologies (replacement pockets, second generation cupolas and pockets, vents, half tube wall and ceiling channels), formed by condensation-corrosion by sulfuric vapors (second phase), with second phase morphologies partly or completely imprinted onto the first phase morphologies.

In the first phase (Pliocene-Early Pleistocene?), cave passages were formed by dissolution of marbles due to cooling of thermal carbonated waters, and were later covered with thick calcite crust deposits due to shift in shallower phreatic environment. These passages were then completely filled with clay deposits, originating from weathering of pyroclastic sediments of Mariovo Formation, which were deposited in lacustrine environment (Early Pleistocene). Between 1.8 and 1.6 Ma BP, Mariovo Lake drained and Buturica River incised first in deposits of Mariovo Formation, then forming superimposed valley and cutting trough the Cambrian marbles. This lowered the water table, and allowed removal of clay deposits. After introduction of $\mathrm{H}_{2} \mathrm{~S}$ in the thermal waters (formed probably by reduction of sulfates in the nearby coal basin), oxidation produced sulfuric acid that rapidly dissolved first calcite crust, then marble host rock, with condensation-corrosion by sulfuric vapors producing replacement of carbonate rock with gypsum. At contact of sulfuric acid with clay 


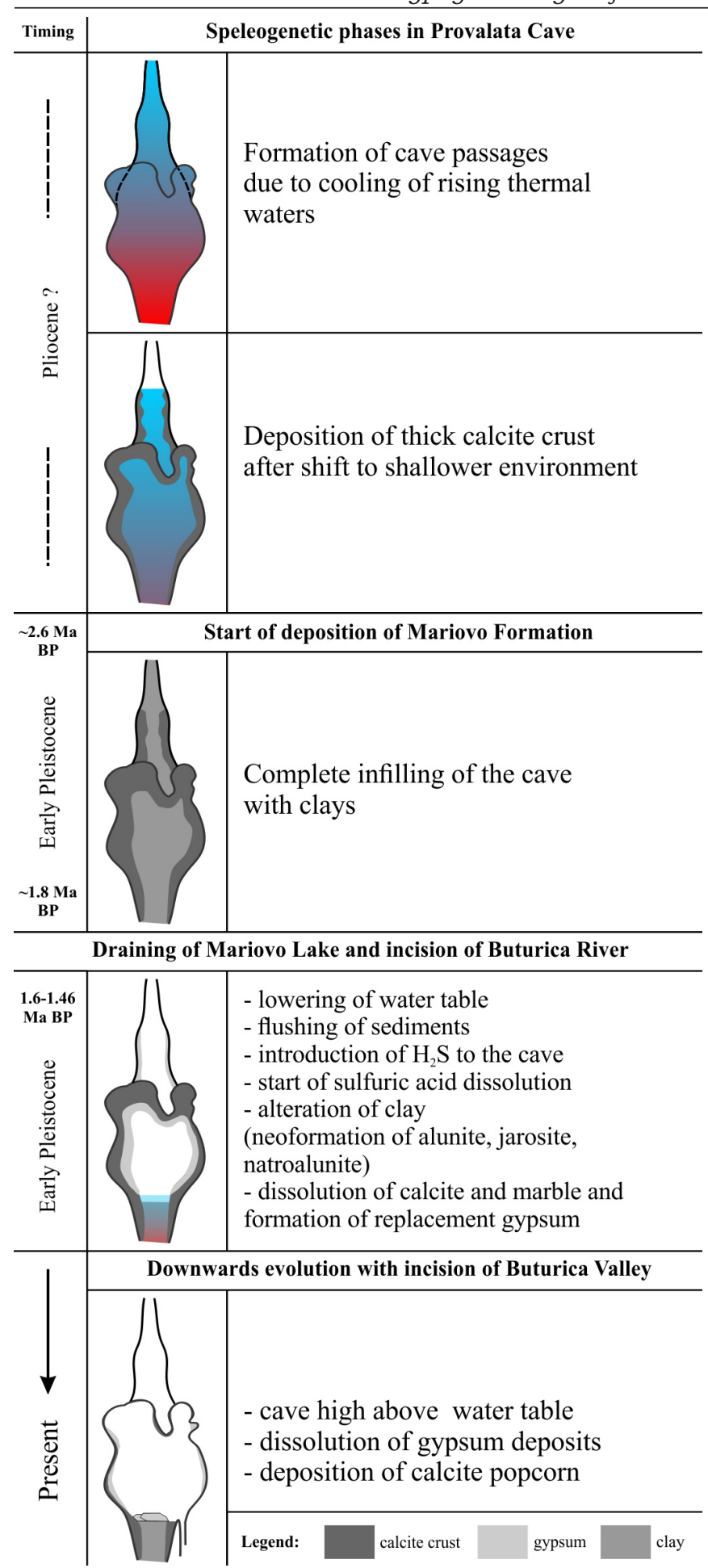

Fig. 9. Schematic representation of the evolution of Provalata Cave.

deposits, alunite, jarosite, and natroalunite were formed, giving a maximum age of $1.6 \mathrm{Ma}$ (alunite) and $1.46 \mathrm{Ma}$ (jarosite) by ${ }^{40} \mathrm{Ar} /{ }^{39} \mathrm{Ar}$ dating. As Buturica River incised, the water table lowered and the sulfuric acid dissolution shifted downward. Today Provalata Cave is $100 \mathrm{~m}$ above the riverbed of Buturica River, where a small low temperature thermal spring (Melnica Spring) is located.

\section{ACKNOWLEDGEMENTS}

Z. Angeleski, M. Andonoski, D. Jovanoski, D. Nedanoski, and M. Dameski are acknowledged for helping with resurveying the cave and collecting samples. Field work was done in the frame of French-
Slovene bilateral Proteus project 22648ZK. We also wish to thank the reviewers whose constructive comments improved the paper.

\section{REFERENCES}

Audra P., 2007 - Karstet spéléogenèse épigènes, hypogènes, recherches appliquées et valorisation (Epigene and hypogene karst and speleogenesis. Operative research and valorization). Habilitation Thesis, University of Nice Sophia-Antipolis, $278 \mathrm{p}$.

Audra P., Hoblea F., Bigot J.-Y. \& Nobecourt J.-C., 2007 - The role of condensation-corrosion in thermal speleogenesis. Study of a hypogenic sulfidic cave in Aixles-Bains, France. Acta Carsologica, 37 (2): 185-194.

Audra P., Mocochain L., Bigot J.-Y. \& Nobecourt J.-C., 2009a - The association between bubble trails and folia: a morphological and sedimentary indicator of hypogenic speleogenesis by degassing, example from Adaouste Cave (Provence, France). International Journal of Speleology, 38 (2): 93-102. http://dx.doi.org/10.5038/1827-806X.38.2.1

Audra P., Mocochain L., Bigot J.-Y. \& Nobecourt J.C., 2009b - Morphological indicators of speleogenesis: hypogenic speleogens. In: Klimchouk A. and Ford D.C. (Eds.), Hypogene speleogenesis and karst hydrogeology of artesian basins. Ukrainian Institute of Speleology and Karstology, Simferopol, Special Paper 1: 17-22.

Clauzon G., Suc J-P., Dumurdžanov N., MelinteDobrinescu M. \& Zagorchev I., 2008 - The Pliocene Gilbert-type fan delta of Dračevo (Skopje area, Republic of Macedonia). Geologica Macedonica, 2: 21-28.

Dublyansky Y.V., 2000a - Dissolution of carbonates by geothermal waters. In: Klimchouk A., Ford D.C., Palmer A.N. \& Dreybrodt W. (Eds). Speleogenesis: evolution of karst aquifers. Huntsville: National Speleological Society: 158-159.

Dublyansky Y.V., 2000b - Hydrothermal speleogenesis - its settings and peculiar features. In: Klimchouk A., Ford D.C., Palmer A.N. \& Dreybrodt W., (Eds). Speleogenesis: evolution of karst aquifers. Huntsville: National Speleological Society: 292-297.

Dumurdžanov N. \& Hristov S., 1976 - General Geological map of SFRJ in 1:100 000: sheet Vitolište. Federal Geological Survey, Beograd (in Macedonian).

Dumurdžanov N., Hristov S., Pavlovski B. \& Ivanova V., 1976 - Explanatory notes for the General Geological map of SFRJ: sheets Vitolište and Kajmakčalan. Federal Geological Survey, Beograd: 61 p. (in Macedonian).

Dumurdžanov N., Serafimovski T. \& Burchfiel, B.C., 2004 - Evolution of the Neogene-Pleistocene Basins of Macedonia. Geological Society of America: Digital Map and Chart Series 1: 1-20.

Dumurdžanov N., Serafimovski T. \& Burchfiel B.C., 2005 - Cenozoic tectonics of Macedonia and its relation to the South Balkan extensional regime. Geological Society of America: Geosphere, 1 (1): 1-22.

Egemeier S.J., 1981 - Cavern development by thermal waters. NSS Bulletin, 43: 31-51.

Galdenzi S. \& Maruoka T., 2003 - Gypsum deposits in the Frasassi caves, Central Italy. Journal of Cave and Karst Studies, 65: 111-125.

Galdenzi S. \& Menichetti M., 1995 - Occurrence of hypogenic caves in a karst region: examples from central Italy. Environmental Geology, 26: 39-47. http://dx.doi.org/10.1007/BF00776030

Hill C.A., 2000 - Overview of geological history of cave development in the Guadalupe Mountains, New Mexico. Journal of Cave and Karst Studies, 62 (2): 60-71. 
Hose L.D. \& Pisarowicz J.A., 1999 - Cueva de Villa Luz, Tabasco, Mexico: reconnaissance study of an active sulfur spring cave and ecosystem. Journal of Cave and Karst Studies 61: 13-21.

Klimchouk A., 2007 - Hypogene speleogenesis: hydrogeological and morphogenetic perspective. NCKRI Special Paper 1. National Cave and Karst Research Institute, Carlsbad, $106 \mathrm{p}$.

Kolios N., Innocenti F., Maneti P., Poccerilo O. \& Guiliani O., 1980 - The Pliocene volcanism of the Voras Mts (Central Maceodonia, Greece). Bulletin of Volcanology, 43 (3): 553-568.

http://dx.doi.org/10.1007/BF02597692

Kolčakovski D., Boev B., Hristovski S. \& Petreska B., 2004 - Cave Gulabinka - Mariovo, preliminary speleological exploration. Bulletin for Physical Geography, Institute of Geography - PMF, Skopje, 1: 35-43 (in Macedonian).

Lerouge C., Gouin J., Deschamps Y., Widory D., LaggounDefarge F., Tasev G., Serafimovski T. \& Yossifova M., 2007 - Characterization of coal from the Mariovo basin, Macedonia - Insights from organic geochemical and sulphur isotopic data. In: Andrew, C.J. \& Borg, G., (Eds). Digging Deeper, 9th Biennial SGA Meeting, August 20-23, 2007, Dublin, Ireland, vol. II: 901-904.

Onac B.P., Wynn J.G \& Sumrall J.G., 2011 - Tracing the sources of cave sulfates: a unique case from Cerna Valley, Romania. Chemical Geology, 288: 105-114. http://dx.doi.org/10.1016/j.chemgeo.2011.07.006

Palmer A.N., 1991 - Origin and morphology of limestone caves. Geological Society of America Bulletin, 103 (1): 1-21. http://dx.doi.org/10.1130/00167606(1991)103<0001:OAMOLC $>2.3 . \mathrm{CO} ; 2$
Palmer A.N., 2007 - Cave Geology. Cave Books, Dayton, Ohio, $454 \mathrm{p}$.

Palmer A.N. \& Palmer M.V., 2000 - Hydrochemical interpretation of cave patterns in the Guadalupe Mountains, New Mexico. Journal of Cave and Karst Studies, 62: 91-108.

Palmer A.N., 2013 - Sulfuric acid caves: Morphology and evolution. In: Shroder J.F. (Ed.), Treatise on Geomorphology, Volume 6: Karst Geomorphology. San Diego: Academic Press: 241-257.

Plan L., Tschegg C., De Waele J. \& Spötl C., 2012. - Corrosion morphology and cave wall alteration in an Alpine sulfuric acid cave (Kraushöhle, Austria). Geomorphology, 169-170: 45-54. http://dx.doi.org/10.1016/j.geomorph.2012.04.006

Polyak V.J. \& Provencio P., 2001 - By-product materials related to $\mathrm{H}_{2} \mathrm{~S}-\mathrm{H}_{2} \mathrm{SO}_{4}$ influenced speleogenesis of Carlsbad, Lechuguilla, and other caves of the Guadalupe Mountains, New Mexico. Journal of Caves and Karst Science, 63 (1): 23-32.

Raleva E., Ilijovski Z. \& Todorova D., 2012 - Jaglenovo naogjalište "Mariovo", presmetka na kvalitet $i$ rezervi, II Congress of geologists of Republic of Macedonia, Geologica Macedonica, Special publication, 3: 131-138 (in Macedonian).

Wynn J.G., Sumrall J.G. \& Onac B.P., 2010 - Sulfur isotopic composition and the source of dissolved sulfur species in thermo-mineral springs of the Cerna Valley, Romania. Chemical Geology, 271: 31-43. http://dx.doi.org/10.1016/j.chemgeo.2009.12.009 